\title{
Returns to Single-Family Owner-Occupied Housing
}

By: G. Donald Jud and Daniel T. Winkler

Jud, G. D. and D. T. Winkler. "Returns to Single-Family Owner-Occupied Housing," Journal of Real Estate Practice and Education, Journal of Real Estate Practice and Education, vol. 8, no. 1, 2005, pp. 25-44.

Made available courtesy of American Real Estate Society: http://www.aresnet.org/OurJournals.htm

***Note: Figures may be missing from this format of the document

\begin{abstract}
:
This study examines the rate of return and risk on single-family, owner-occupied housing nationally and at the MSA level. The homeowner using no leverage, and a $28 \%$ tax rate, earned an $11.81 \%$ annual return, 5.85\% from implicit rental savings and 5.63\% from price appreciation from 1978:1 to 2001:4. The use of leverage increased rates of returns as well as risk, and longer holding periods offered higher returns and lower risk. With an $80 \%$ loan-to-value ratio, homeownership returns were between Treasury bonds and stocks, although with more risk than either. Among the $42 \mathrm{MSAs}$, return and risk varied as much as threefold.
\end{abstract}

\section{Article:}

The Federal Reserve's 2001 Survey of Consumer Finances reveals that $67.7 \%$ of the nation's households are homeowners. For most Americans, investments in their homes are a major part of their accumulated wealth. The primary residence of the average homeowner household is valued at $\$ 180,800$, accounting for $28.5 \%$ of the total assets of homeowner households. 1

The stock market decline that occurred at the beginning of the millennium has damaged investor confidence in financial markets, resulting in a substantial loss of wealth, but may have also helped fuel growth in the housing sector. During this period, homeownership proved to be an important asset mitigating the effects of stock market losses on household net worth and spending patterns.2 Reviewing these trends, Alan Greenspan (2001) speculated that housing price changes have a larger effect on consumer spending than stock price movements. Although the fear of a housing market bubble has been reported in the popular press (Fuerbringer, 2002; and Smith, 2002), housing affordability has been high (Barnes, 2002), and homeownership has emerged as an important investment alternative. 3

While previous research has offered insight into investment returns of single-family, owneroccupied housing, such studies often had serious limitations. Many did not include key inputs in the rate of return calculation such as transaction costs, maintenance and insurance costs, and imputed rent. To the authors' knowledge, even more recent research has not included the effects of refinancing, which is prevalent today given the low fixed costs of refinancing. When researchers included key inputs, they sometimes relied on "rules of thumb" instead of empirical data. In addition, quality-adjusted housing price data was not readily available until recently; therefore, most studies had small samples. The quality-adjusted housing price index from the 
Office of Federal Housing Enterprise Oversight (OFHEO) has been recently released, and it is very extensive. This database provides an opportunity to examine the returns and risks of homeownership using quarterly prices from 1978 through 2001, including aggregate national data, as well as data from 42 MSAs.

The first section of the paper surveys prior research. The second section sets out the internal rate of return (IRR) model employed to measure returns. The third section discusses the empirical data used in the analysis. The fourth section examines the returns and risks of homeownership drawing on aggregate national data. The fifth section looks at the variation in returns among a sample of 42 MSAs. And the final section summarizes relevant findings and sets forth conclusions.

\section{Survey of Past Research}

The risks and returns of including single-family housing as part of an overall investment portfolio has been studied by case and Shiller (1987, 1990), Devaney and Rayburn (1988), Crone and Voith (1999), Liu, Grissom and Hartzell (1990), Goetzmann (1993) and others.4 These studies indicate the advantages of housing market diversification (e.g., by geographic area), as well as the benefits of combining residential real estate with stocks and bonds. This research, however, finds that housing investment is unlike stock investment because of the following: (1) the consumption-investment link; (2) the illiquid nature of real estate; (3) the serial correlation in housing prices; and (4) the housing market inefficiencies in general. More recent studies of single-family home prices indicate that prices are mean-reverting (Englund, Gordon and Quigley, 1999) and first-order serially correlated (Quigley and Redfearn, 2000). However, it is unclear if rates of return to homeowners are linked to house value, and therefore, indirectly related to household income.5

Studies of the effects of taxes on homeownership have been inconclusive. Berkovec and Fullerton (1992) conduct a simulation and find that the removal of tax benefits of owneroccupied housing would decrease homeownership by $3 \%$ to $6 \%$. Their study indicates that highincome taxpayers would consume less housing, while lower-income taxpayers would consume more.6 This view of the effect of taxes is shared by Rosen, Rosen and Holz-Eakin (1984) and others.7 Tse and Webb (1999) conclude that the property tax is capitalized into housing rents and that a capital gains tax impairs the liquidity of property and lowers the rate of return on property investments. Sheffrin and Turner (2001) argue that households are not better off as a result of a capital gains tax because the tax-induced reduction in volatility does not offset the increased user cost of the tax. While the precise effects of taxation of homeownership remain unclear, the need to include tax effects in rate of return calculations is imperative.

Calculating the rate of return on investments in owner-occupied, single-family housing has proven to be complex because of the transaction costs, taxes and implicit rent embedded in the rate of return calculations. Moreover, data availability has impaired much of the empirical work in this area.

Coyne, Goulet and Picconi (1980) calculate the rates of return for single-family housing from 1969 to 1977 using monthly data on mean sales values for new and existing single-family homes as reported in the Journal of the Federal Home Loan Bank Board. Their findings indicate that 
investments in housing are either negatively correlated or have a low positive correlation with common stocks and bonds and that the use of residential real estate decreases the systematic risk of a household portfolio. Unfortunately, the implicit return (rental income), taxes and transactions costs are assumed to be zero, which limits the usefulness of their findings. In addition, their study focuses on monthly returns, which they compare to monthly stock market returns. They do not calculate returns for longer-term holding periods.

Alberts and Kerr (1981) explore the question of the rate of return that homeowners earn on invested equity capital using a sample consisting of 45 single-family houses in the Salt Lake City MSA during 1970-1974. Although this study includes the use of debt and the taxation of income, transaction costs are not included. They find that the rates of return to homeownership are substantially above those for the S\&P 500 portfolio of common stocks. The mean return on housing ranges from $14.7 \%$ with no debt to $52.3 \%$ with $90 \%$ leverage.

Hendershott and $\mathrm{Hu}$ (1981) estimate the rate of return to homeownership during the 1956-1979 period, using national data. They develop a return model that considers housing appreciation, implicit rent, property taxes and debt service. House prices are estimated using the Bureau of the Census, constant-quality new house price index, and the rental component of the Consumer Price Index (CPI) is used to construct the implicit rent series. They find nominal returns during 196479 ranging from $7.0 \%$ to $10.5 \%$ annually, when calculated for a leveraged home purchase with a $75 \%$ loan-to-value ratio. However, they report negative returns for an earlier 1956-1963 period.

Other researchers have used the housing return model developed by Hendershott and $\mathrm{Hu}$ (1981). Peiser and Smith (1985) add maintenance costs and deduct selling expenses in calculating returns. They use an internal rate of return (IRR) model to calculate average returns nationally for six contiguous four-year holding periods from 1963 to 1981. Calculated annual returns range from $14.4 \%$ during $1963-66$ to $33.1 \%$ during $1975-1978$, assuming an 80\% loan-to-value ratio.

Webb and Rubens (1987a) use national data to calculate a series of one-year holding period returns for homeownership. Using the holding-period return series, they then calculate average returns for particular holding periods by computing geometric means over various time periods. They employ varying assumptions regarding tax rates and the use of leverage when computing returns. In general, their reported returns are substantially lower than those reported by other studies.

Miller and Sklarz (1989) use an IRR model that allows equity build-up from the repayment of principal and gains from loan refinancing when interest rates decline. Assuming transaction costs of $6 \%$, they recalculate returns using data from the Webb and Rubens (1987b) study. For the 1967-1984 period, with a 30\% marginal tax rate and the use of leverage, they report an annual average return of $12.4 \%$.

Ermer, Cassidy and Sullivan (1994) develop a model of returns to owner-occupied single-family residences that includes transaction costs, the use of debt, implied rental cost and taxes. However, their research assumes no refinancing because of changes in interest rates. In addition, imputed rent is not based on the actual rental market, but rather imputed by assuming that the rent achieved would only cover annual after-tax expenses. They assume that the rate of 
appreciation of property is a constant 6.2\%, the average rate over the 1982-1990 period (as reported in the Federal Reserve Bulletin). They further assume (1) a constant mortgage interest rate of $10 \%$ for 30 years; (2) a $30 \%$ federal plus state tax rate; and (3) transactions costs of $3 \%$ at purchase and $6 \%$ at sale. With these assumptions, they calculate the holding period returns for 1 to 30 years, with downpayments of $10 \%, 20 \%$ and $40 \%$. A maximum holding period rate of return of $12.31 \%$ is achieved for a 10 -year holding period, assuming $90 \%$ leverage. 8

Case and Shiller (1990) estimate excess returns (returns above the 3-month Treasury bill rate) to housing investment in four cities (Atlanta, Chicago, Dallas and Oakland) using quarterly data for 1970:1-1986:3. The housing price series they use are qualityadjusted indexes tabulated from the repeat sales of existing homes. The quarterly return series is calculated considering the following: (1) the capital gains from the change in house values; (2) the imputed rental savings from homeownership; and(3) the after-tax cost of property taxes, home maintenance and interest. They make no allowance for transaction costs or refinancing. They report very high excess returns for the four cities in the 1970s, followed by negative returns in the early 1980s.

Harris (2002) follows the approach developed by case and Shiller (1990) and computes average annual returns using national data for the period 1987-2000. Assuming an 80\% loan-to-value ratio, he reports annual returns that range from a low of $-14.8 \%$ in 1990 to a high of $34.5 \%$ in 2000. Housing price appreciation is measured using the National Association of Realtors ${ }^{\circledR}$ (NAR) median price of existing homes sold, and imputed rent is estimated using Annual Housing Survey (AHS) data. Harris assumes that transaction costs are amortized over a 10-year period.

Overall, past research reveals the returns to housing investment are related to the following: (1) home price appreciation; (2) income tax rates; (3) mortgage leverage; (4) transaction costs; (5) insurance and maintenance expenses; (5) property taxes; and (6) the imputed rental value of the dwelling unit. The imputed rental value of the housing unit reflects the savings obtained by the homeowner by not having to pay rent on the dwelling.9 Researchers have shown that this is an important component of the overall return to housing, and since it is not subject to income taxation, this component of the homeowner's overall return is conceptually similar to the tax-free return on a municipal bond.

A notable shortcoming in past studies is the neglect of the importance of the refinancing option in the traditional fixed-rate home mortgage. During periods of falling interest rates, the ability to refinance is likely to generate substantial equity gains for homeowners. The following analysis explicitly considers the refinancing option.

\section{The Investment Returns Model}

The largest gains to homeownership stem from two sources: (1) the implicit savings of out-ofpocket rental expenses; and (2) capital gains arising from housing price appreciation. Homeowners incur expenses from the payment of mortgage interest, property taxes, and insurance and maintenance. Additionally, high transaction costs in the housing market force homeowners to incur expenses both when they buy and when they sell. Because of the high transactions costs, the returns to homeownership are examined over various holding periods. 
Following Miller and Sklarz (1989) and others, the returns to homeownership are measured using the internal rate of return (IRR) model, which can be written as follows:

$$
\frac{I C O_{0}}{(1+r)^{0}}=\sum_{t=1}^{n} \frac{A C F_{t}}{(1+r)^{t}}+\frac{E P R_{n}}{(1+r)^{\prime}},
$$

where:

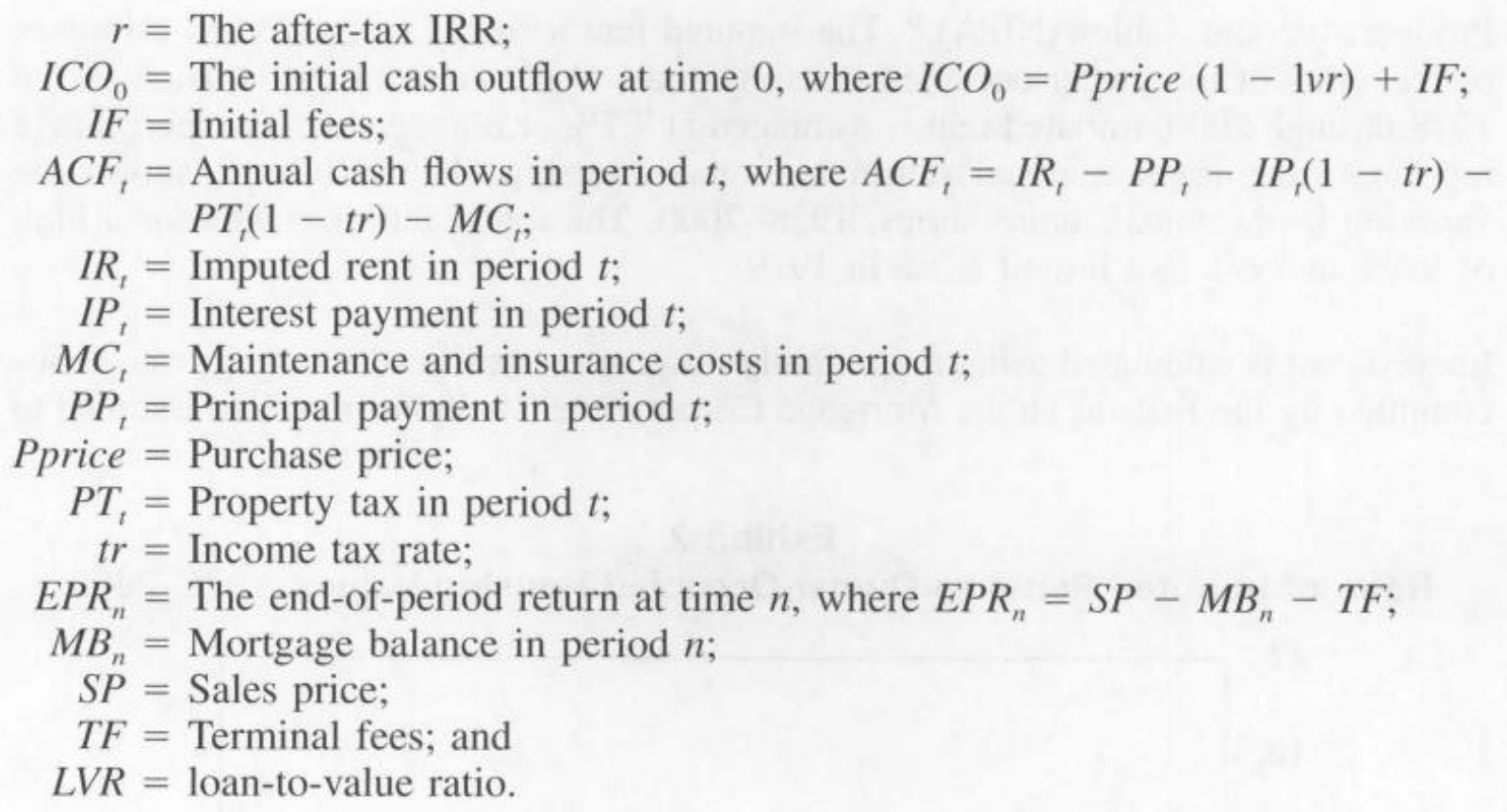

\section{Empirical Data}

Estimation of the after-tax IRR for homeownership requires a number of assumptions. Home prices are measured using the Office of Federal Housing Enterprise Oversight (OFHEO) qualityadjusted price index for existing homes in the United States. Exhibit 1 shows the house price index from 1978 through 2001. The average rate of house price appreciation during this period was $4.3 \%$ annually.

Implicit rents are estimated using the Bureau of Economic Analysis (BEA) series on imputed rents for owner-occupied housing, taken from the National Income and Product Account Tables (NIPA).10 The imputed rent series is derived from estimates of the value of the owner-occupied housing stock, also estimated by the BEA. From 1978 through 2000, imputed rent is estimated at $7.7 \%$ of home value. This percentage represents the implicit rental return to homeownership. The Exhibit 2 shows the variation in the rental return series, 1978-2000. The rental return ranges for a high of $8.5 \%$ in 1991 to a low of $6.3 \%$ in 1979. 


\section{Exhibit 1 \\ OFHEO Existing Price Index \\ $(1978=100)$}

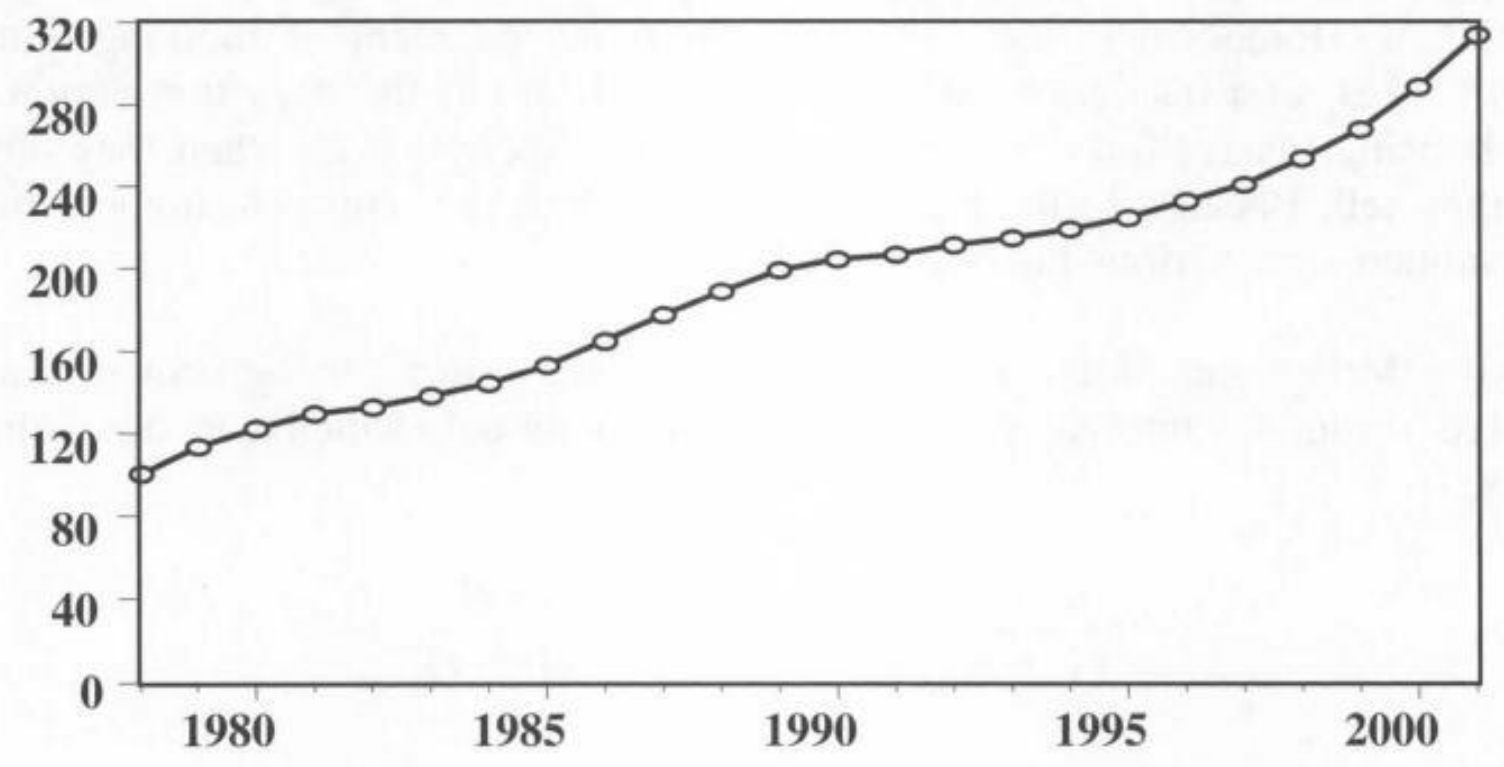

Interest cost is calculated using the monthly 30-year conventional mortgage rate series compiled by the Federal Home Mortgage Corporation. The homeowner is assumed to refinance the loan whenever the market rate drops $2 \%$ below the initial rate and is assumed to pay a cost equal to $1.5 \%$ of the outstanding balance on the loan. 


\section{Exhibit 2}

Ratio of Imputed Rents to Owner-Occupied Housing Values: 1978-2000

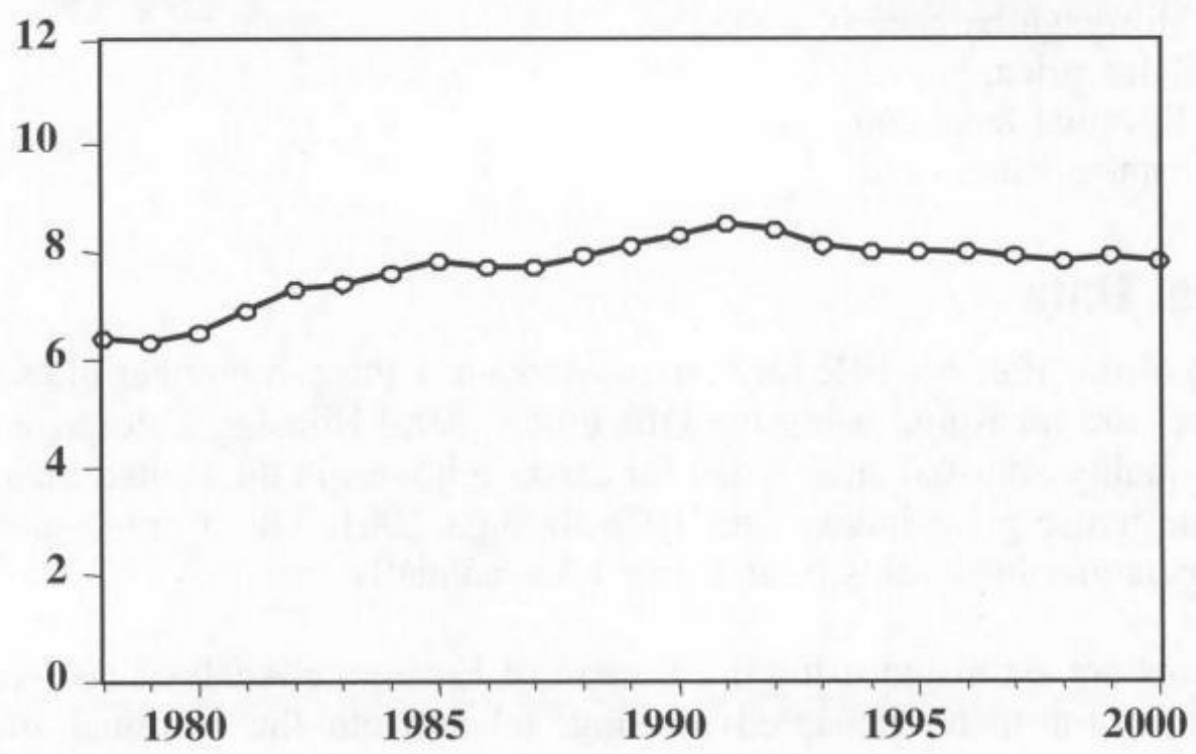

Property taxes are calculated based on data taken from the Census Bureau's AHS. On the basis of AHS data for 1993 and 1999, property taxes are assumed to be 1.06\% of housing value annually.

Maintenance and insurance costs also are calculated using estimates from AHS data. Based on AHS data for 1993 and 1999, the average homeowner is estimated to spend $0.72 \%$ of the value of the home on maintenance and insurance. In the housing market, transaction costs are not trivial and their effect on returns cannot be ignored. Initial fees and charges are assumed to be $2 \%$ of the purchase price, and terminal fees are assumed to be $6 \%$ of the sales price.

\section{Investment Returns Using a National Sample}

Employing the investment model shown in Equation (1), a homeowner who purchased a home in the first quarter of 1978 and held it through the fourth quarter of 2001 would have earned the returns shown in Exhibit 3, depending on the homeowner's marginal tax rate. With no leverage and a $28 \%$ marginal tax rate, the average homeowner earned a compound annual return of $11.81 \%, 5.85 \%$ from implicit rental savings and 5.63\% arising from the appreciation in home prices. At a 15\% marginal tax rate, the homeowner's total return was $11.65 \%$ annually, of which the increase in home prices yielded 5.62\% annually. With leverage, the returns over this period increased substantially. 


\section{Exhibit 3}

Annual Compound Returns to Homeownership: 1978:1-2001:4

\begin{tabular}{|c|c|c|c|c|c|}
\hline & \multicolumn{5}{|c|}{ Percent Leverage } \\
\hline & $0 \%$ & $70 \%$ & $80 \%$ & $90 \%$ & $95 \%$ \\
\hline \multicolumn{6}{|c|}{ Panel A: $15 \%$ Tax Rate } \\
\hline Total Return & $11.65 \%$ & $16.62 \%$ & $18.36 \%$ & $21.16 \%$ & $23.48 \%$ \\
\hline Imputed Rent & $5.71 \%$ & $7.13 \%$ & $7.60 \%$ & $8.30 \%$ & $8.79 \%$ \\
\hline Capital Gain & $5.62 \%$ & $8.86 \%$ & $10.00 \%$ & $11.87 \%$ & $13.50 \%$ \\
\hline \multicolumn{6}{|c|}{ Panel A: $28 \%$ Tax Rate } \\
\hline Total Return & $11.81 \%$ & $18.14 \%$ & $20.60 \%$ & $25.01 \%$ & $29.30 \%$ \\
\hline Imputed Rent & $5.85 \%$ & $8.79 \%$ & $9.90 \%$ & $11.70 \%$ & $13.19 \%$ \\
\hline Capital Gain & $5.63 \%$ & $8.59 \%$ & $9.74 \%$ & $11.92 \%$ & $14.23 \%$ \\
\hline
\end{tabular}

Note: Total Return $=(1+$ Imputed Rent $) \times(1+$ Capital Gain $)-1$ where all three terms are expressed as rates and in decimal form.

Imputed rent in Exhibit 3 represents a large fraction of the total return to homeownership. In the $28 \%$ tax bracket with $80 \%$ leverage, imputed rent accounts for $50.4 \%$ of total return. With zero leverage, rental savings are $51 \%$ of total return.

To examine the variation in returns, Exhibit 4 shows a series of holding period returns constructed beginning in 1978:1 by computing all possible 3-, 5- and 10-year holding periods. Average returns and standard deviations are calculated for various tax rates and loan-to-value ratios.

The findings in Exhibit 4 indicate that longer holding periods are associated with higher average returns and lower risk, where risk is measured by the standard deviation in returns or the coefficient of variation. This is because longer holding periods reduce the per-period effect of transaction costs by spreading these costs over longer time periods.

With leverage, longer holding periods also dissipate the effect of the interest rate tax subsidy, as the initial mortgage is amortized over longer holding periods. However, this effect is swamped by the transaction cost effect. The relationship between holding periods and homeowner returns and risks is illustrated in Exhibit 5, which assumes a 28\% marginal tax rate and an 80\% loan-tovalue ratio.

The effect of leverage on the rate of return and risk also varies with the personal tax rate. As shown in Exhibit 4, for homeowners in the 15\% marginal tax bracket investing for a 3-year holding period, leveraging their home investment reduces their average return. The nonleveraged return for this group is $7.79 \%$, but with $95 \%$ leverage, the return falls to $1.47 \%$. For all other holding periods and tax rates shown in Exhibit 4, additional leverage raises homeownership returns." While higher leverage does not always result in higher returns, additional leverage 
always raises the level of investment risk. Whether risk is measured by the standard deviation of quarterly returns or the coefficient of variation, risk increases with leverage for all of the tax rate/holding period combinations.

Higher marginal tax rates, of course, produce a greater subsidy to homeownership because of the deductibility of interest and property taxes and, thus, provide higher average returns. But higher tax rates also reduce the risk of homeownership by allowing higher income taxpayers to pass along a greater share of their interest and property taxes to the federal government, thereby mitigating the effects of high interest rates on property returns. Exhibit 6 illustrates the relationship between tax rates, returns and risk, assuming 5-year holding periods and an $80 \%$ loan-to-value ratio.

Exhibit 7 compares the S\&P 500 stock index, Treasury bonds, Treasury bills and the inflation rate to homeownership returns for 5-year holding periods from 1978 to 1996 (homeownership returns are computed using a $28 \%$ marginal tax rate and an $80 \%$ loan-to-value ratio). 12 The findings suggest that homeownership returns are substantially greater than T-bills, T-bonds and inflation, but lower than stock market returns. The level of investment risk of homeownership (as measured by the standard deviation and coefficient of variation) is greater than bills, bonds and stocks. Of course, the homeownership returns reflect a personal leveraged investment, whereas, the other financial market returns do not.13 Exhibit 8 plots the return series summarized in Exhibit 7. 


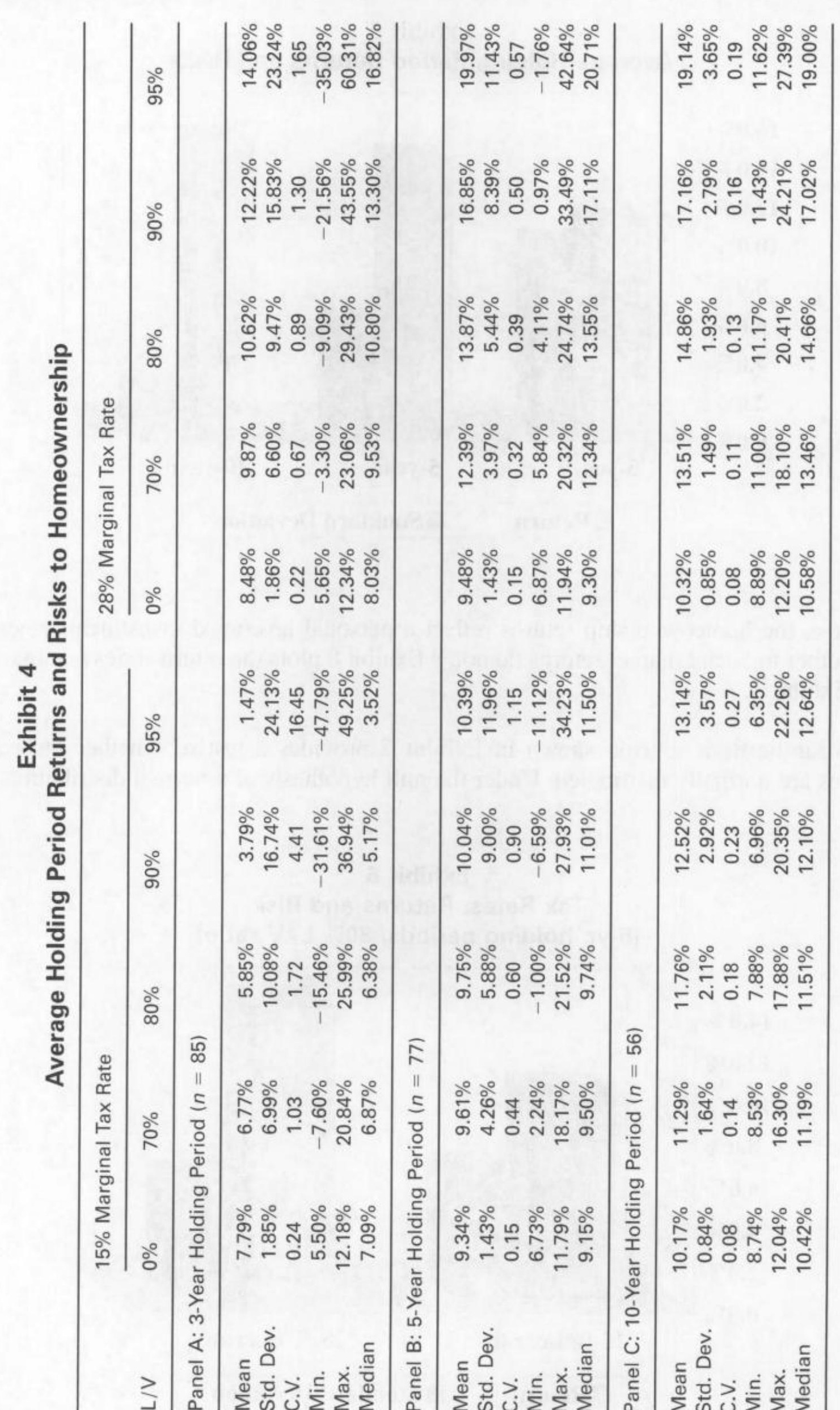




\section{Exhibit 5}

Average Holding Period Returns and Risks

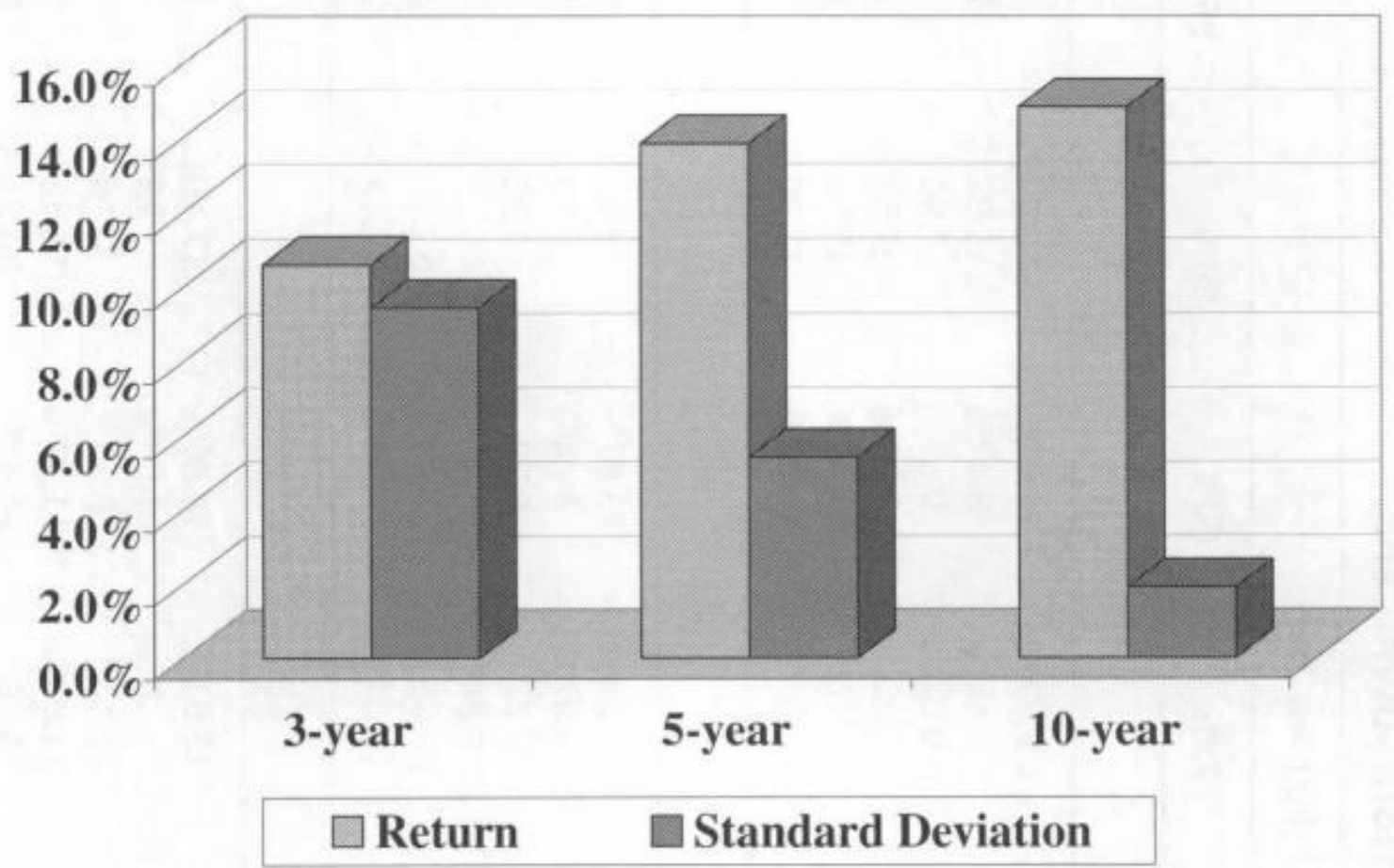




\section{Exhibit 7}

Returns to Homeownership and Financial Assets, 1978-1996

\begin{tabular}{lccccr}
\hline & Homeownership & T-Bills & T-Bonds & S\&P 500 & CPI-U \\
\hline Mean & 13.75 & 6.95 & 10.75 & 17.50 & 3.94 \\
Median & 13.60 & 6.75 & 10.30 & 16.54 & 3.60 \\
Maximum & 23.82 & 11.08 & 19.95 & 28.42 & 8.83 \\
Minimum & 5.31 & 4.22 & 6.94 & 9.19 & 2.36 \\
Std. Dev. & 5.32 & 2.35 & 3.48 & 4.18 & 1.70 \\
C.V. & 0.39 & 0.34 & 0.32 & 0.24 & 0.43 \\
Skewness & 0.01 & 0.65 & 1.15 & 0.81 & 1.69 \\
Jarque-Bera & 0.74 & 1.96 & 4.60 & 3.29 & 13.15 \\
Probability & 0.69 & 0.38 & 0.10 & 0.19 & 0.00 \\
\hline
\end{tabular}

Note: There are 19 observations. Data are annual returns for 5 -year holding periods.

\section{Exhibit 8}

Returns to Homeownership and Financial Assets

(5-year holding periods, homeownership assumes a $28 \%$ tax rate, $80 \% \mathrm{~L} / \mathrm{V}$ )

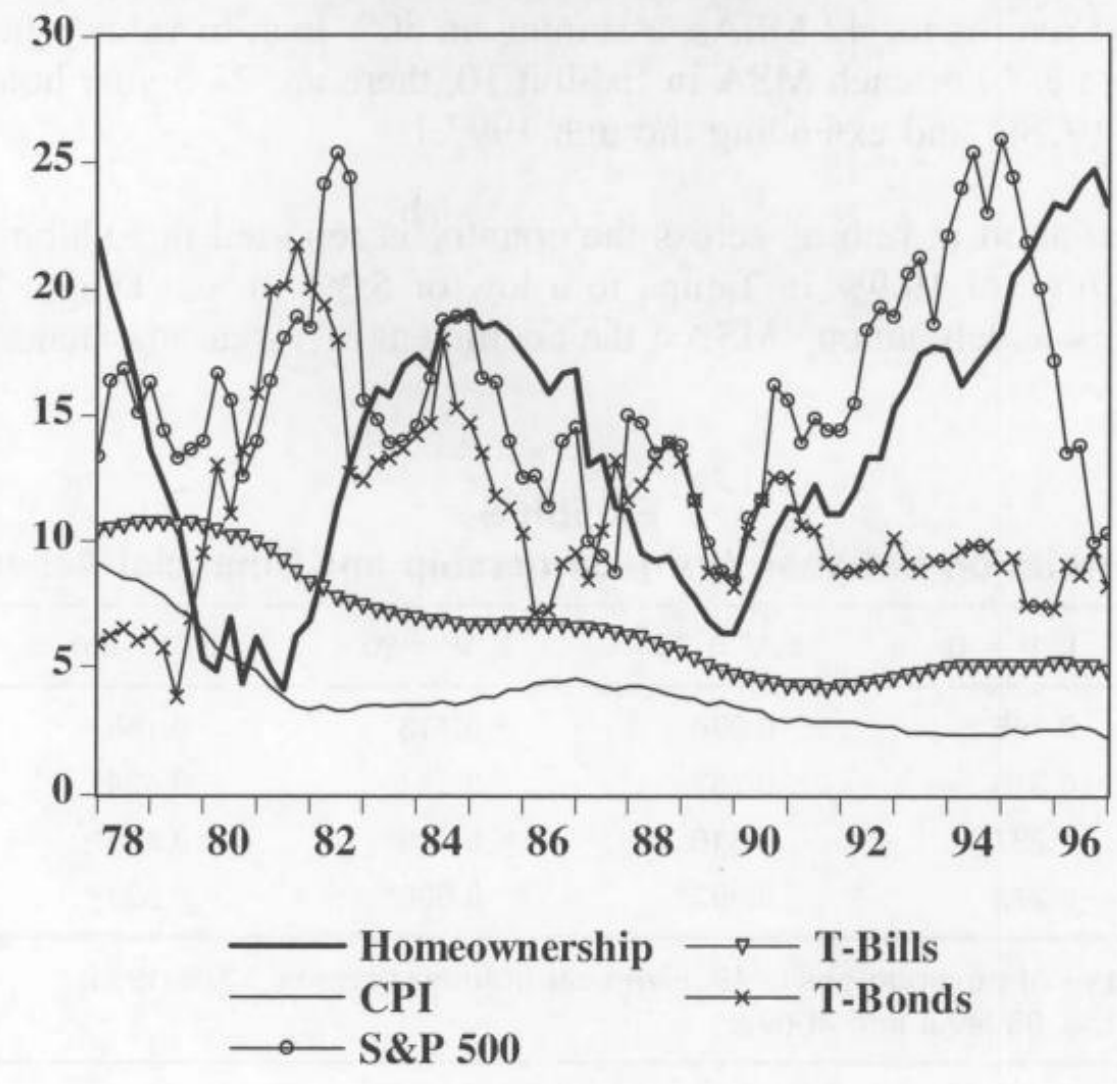


Exhibit 9 examines the correlation between 5-year holding period, homeownership returns (calculated using a $28 \%$ marginal tax rate and various loan-to-value ratios) and financial assets and inflation (measured by the CPI-U). For stocks, all the correlation coefficients shown in Exhibit 9 are positive and all are statistically significant at the .05-level or above except for the non-leveraged return series $(\mathrm{L} / \mathrm{V}=0)$. The correlation coefficients reveal that the correlation of homeownership returns with stocks rises with increasing leverage. For other financial assets, the correlation with homeownership returns is negative in every case except for the non-leveraged return series, where the correlation is positive but not statistically significant.

The correlation of inflation and homeownership returns also is negative in all cases except for the non-leveraged return series. Additionally, the correlation coefficients in Exhibit 9 are statistically insignificant in all cases. These results cast doubt on the use of homeownership as an inflation hedge.

\section{Investment Returns Using an MSA Sample}

The OFHEO data make possible the calculation of homeownership returns for metropolitan statistical areas (MSAs). Exhibit 10 presents averages of the 5-year holding period returns for 42 MSAs, assuming an $80 \%$ loan-to-value ratio and a $28 \%$ marginal tax rate. 14 For each MSA in Exhibit 10, there are 77 5-year holding periods beginning in 1978:1 and extending through 1997:1.

Substantial variation in returns across the country is reported in Exhibit 10. Returns range from a high of $19.9 \%$ in Tampa to a low of $5.3 \%$ in San Diego. The level of risk also differs widely

among MSAs: the coefficient of variation extends from a low of 0.29 in Norfolk to a high of 3.19 in Sacramento. The correlation between return and risk (standard deviation) among the $42 \mathrm{MSAs}$ in Exhibit 10 is not positive as might be expected. Rather the correlation is a -0.51 , which is significant at the .01level and above.

\section{Exhibit 9}

Correlation between Homeownership and Financial Assets

\begin{tabular}{llcccc}
\hline & $\mathrm{L} / \mathrm{V}=0$ & $\mathrm{~L} / \mathrm{V}=70$ & $\mathrm{~L} / \mathrm{V}=80$ & $\mathrm{~L} / \mathrm{V}=90$ & $\mathrm{~L} / \mathrm{V}=95$ \\
\hline CPI-U & 0.165 & -0.074 & -0.113 & -0.168 & -0.196 \\
T-Bills & 0.316 & -0.267 & -0.344 & -0.424 & $-0.471^{*}$ \\
T-Bonds & 0.287 & -0.316 & -0.389 & $-0.458^{*}$ & $-0.494^{*}$ \\
S\&P 500 & 0.273 & $0.492^{*}$ & $0.506^{*}$ & $0.523^{*}$ & $0.537^{*}$ \\
\hline
\end{tabular}

Note: The number of observations is 19. Five-year holding periods: 1978-1996.

*Significant at the .05 level and above. 
Exhibit 10

Average Returns for Five-Year Holding Periods: 1978-2001 ${ }^{\text {a }}$

\begin{tabular}{|c|c|c|c|c|c|c|}
\hline MSA & $\begin{array}{l}\text { Mean } \\
(\%)\end{array}$ & $\begin{array}{l}\text { Std. Dev. } \\
(\%)\end{array}$ & C.V. & $\begin{array}{l}\text { Min. } \\
(\%)\end{array}$ & $\begin{array}{l}\text { Max. } \\
(\%)\end{array}$ & $\begin{array}{l}\text { Median } \\
(\%)\end{array}$ \\
\hline Anaheim, $\mathrm{CA}^{\mathrm{b}}$ & 10.7 & 14.6 & 1.36 & -23.4 & 28.5 & 14.1 \\
\hline Atlanta, GA & 19.1 & 6.5 & 0.34 & 9.5 & 32.1 & 17.8 \\
\hline Baltimore, MD & 10.1 & 7.2 & 0.71 & -0.9 & 22.7 & 9.3 \\
\hline Birmingham, AL & 14.6 & 6.7 & 0.46 & -3.5 & 24.2 & 14.3 \\
\hline Boston, MA & 12.2 & 20.6 & 1.69 & -28.3 & 40.6 & 18.0 \\
\hline Buffalo, NY & 7.5 & 9.2 & 1.22 & -6.4 & 24.8 & 4.6 \\
\hline Charlotte, NC & 16.9 & 5.4 & 0.32 & 5.1 & 25.5 & 18.2 \\
\hline Chicago, IL & 8.5 & 7.6 & 0.89 & -8.3 & 20.1 & 8.8 \\
\hline Cincinnati, $\mathrm{OH}$ & 8.5 & 8.0 & 0.94 & -11.5 & 17.4 & 11.2 \\
\hline Cleveland, $\mathrm{OH}$ & 9.6 & 10.0 & 1.04 & -13.0 & 18.5 & 15.1 \\
\hline Columbus, $\mathrm{OH}$ & 12.7 & 7.1 & 0.56 & -6.7 & 20.5 & 15.3 \\
\hline Dallas, TX & 6.1 & 14.7 & 2.40 & -23.5 & 32.3 & 9.1 \\
\hline Denver, CO & 8.6 & 17.4 & 2.03 & -22.8 & 30.5 & 14.2 \\
\hline Detroit, MI & 15.1 & 15.0 & 0.99 & -20.9 & 30.8 & 19.5 \\
\hline Fort Worth, TX & 11.7 & 12.0 & 1.03 & -9.7 & 35.0 & 12.9 \\
\hline Houston, $\mathrm{TX}^{\mathrm{b}}$ & 11.4 & 12.9 & 1.14 & -27.4 & 28.9 & 13.6 \\
\hline Indianapolis, IN & 13.9 & 7.2 & 0.52 & -9.9 & 21.0 & 16.5 \\
\hline Kansas City, MO & 13.1 & 9.4 & 0.72 & -6.6 & 29.4 & 9.9 \\
\hline Los Angeles, $\mathrm{CA}^{\mathrm{b}}$ & 10.5 & 14.3 & 1.36 & -26.7 & 30.5 & 11.9 \\
\hline Memphis, TN & 16.3 & 6.3 & 0.39 & 2.3 & 26.2 & 15.4 \\
\hline Miami, FL' & 11.9 & 10.4 & 0.88 & -17.9 & 32.6 & 14.8 \\
\hline Milwaukee, WI & 6.4 & 11.3 & 1.75 & -21.6 & 16.5 & 13.0 \\
\hline Minneapolis, MN & 9.9 & 9.0 & 0.91 & -6.1 & 28.9 & 7.8 \\
\hline New Orleans, LA & 8.4 & 17.2 & 2.04 & -24.9 & 28.4 & 14.5 \\
\hline New York, NY & 10.3 & 19.6 & 1.91 & -24.9 & 40.4 & 16.1 \\
\hline Newark, NJ & 8.0 & 17.0 & 2.12 & -26.8 & 37.4 & 12.9 \\
\hline Norfolk, VA & 15.2 & 4.5 & 0.29 & 7.4 & 28.0 & 15.1 \\
\hline Oklahoma City, OK ${ }^{\mathrm{b}}$ & 14.5 & 16.0 & 1.10 & -29.8 & 39.3 & 21.2 \\
\hline Philadelphia, PA & 12.1 & 11.0 & 0.91 & -6.3 & 30.5 & 11.0 \\
\hline Phoenix, AZ & 13.5 & 11.2 & 0.83 & -5.3 & 34.3 & 10.9 \\
\hline Pittsburgh, PA & 10.9 & 7.7 & 0.71 & -9.1 & 21.0 & 13.5 \\
\hline Portland, OG & 10.7 & 16.4 & 1.54 & -22.8 & 29.4 & 17.2 \\
\hline Providence, RI & 8.4 & 18.2 & 2.18 & -28.6 & 39.2 & 9.7 \\
\hline Riverside, $\mathrm{CA}^{\mathrm{b}}$ & 8.2 & 17.0 & 2.07 & -32.6 & 28.4 & 11.8 \\
\hline Sacramento, CA & 5.4 & 17.3 & 3.19 & -28.4 & 29.2 & 7.0 \\
\hline Salt Lake City, UT & 8.2 & 17.0 & 2.07 & -20.5 & 33.3 & 10.0 \\
\hline San Diego, CA & 5.3 & 16.2 & 3.06 & -24.2 & 28.6 & 6.8 \\
\hline San Francisco, $\mathrm{CA}^{\mathrm{b}}$ & 10.5 & 16.6 & 1.58 & -28.1 & 32.2 & 11.6 \\
\hline
\end{tabular}


Exhibit 10 (continued)

Average Returns for Five-Year Holding Periods: 1978-2001 ${ }^{\mathrm{a}}$

\begin{tabular}{lccrrrr}
\hline MSA & $\begin{array}{l}\text { Mean } \\
(\%)\end{array}$ & $\begin{array}{l}\text { Std. Dev. } \\
(\%)\end{array}$ & C.V. & \multicolumn{1}{c}{$\begin{array}{l}\text { Min. } \\
(\%)\end{array}$} & $\begin{array}{l}\text { Max. } \\
(\%)\end{array}$ & \multicolumn{1}{c}{$\begin{array}{l}\text { Median } \\
(\%)\end{array}$} \\
\hline Seattle, WA & 10.4 & 12.5 & 1.20 & -13.8 & 28.0 & 12.5 \\
St. Louis, MO & 12.5 & 6.0 & 0.48 & -5.1 & 23.5 & 13.0 \\
Tampa, FL & 19.9 & 6.8 & 0.34 & 6.5 & 36.1 & 18.0 \\
Washington, DC & 8.9 & 10.7 & 1.20 & -8.6 & 25.7 & 7.4 \\
U.S. & 13.9 & 5.4 & 0.39 & 4.1 & 24.7 & 13.6 \\
\hline
\end{tabular}

Notes: Table assumes a 30 -year, fixed-rate loan, $80 \%$ L/V ratio and $28 \%$ tax rate.

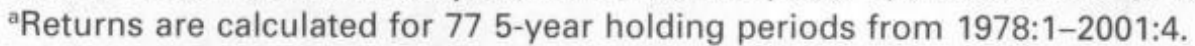

'Because the IRR model yields multiple solutions for some holding periods, the returns for Anaheim, Houston, Los Angeles, Miami, Oklahoma City, Riverside and San Francisco are computed with $65,65,63,76,64,70$ and 735 -year holding periods respectively.

Exhibit 11

Returns for Recent Holding Periods

\begin{tabular}{lllc}
\hline & \multicolumn{2}{l}{ Holding Periods } & \\
\cline { 2 - 4 } MSA & 3 -Year (\%) & 5 -Year (\%) & 10 -Year (\%) \\
\hline Anaheim, CA & 28.5 & 26.4 & 6.2 \\
Atlanta, GA & 33.9 & 31.9 & 23.0 \\
Baltimore, MD & 19.6 & 16.1 & 9.4 \\
Birmingham, AL & 20.1 & 22.0 & 20.4 \\
Boston, MA & 37.1 & 28.5 & 14.6 \\
Buffalo, NY & 3.7 & 5.3 & 4.8 \\
Charlotte, NC & 20.8 & 23.1 & 19.6 \\
Chicago, IL & 18.2 & 14.5 & 11.3 \\
Cincinnati, OH & 15.8 & 16.5 & 14.2 \\
Cleveland, OH & 13.9 & 15.6 & 15.4 \\
Columbus, OH & 18.0 & 18.4 & 16.3 \\
Dallas, TX & 27.0 & 24.5 & 23.9 \\
Denver, CO & 38.7 & 30.0 & 22.0 \\
Detroit, MI & 27.5 & 27.0 & 20.6 \\
Fort Worth, TX & 31.0 & 27.4 & 18.1 \\
Houston, TX & 31.9 & 29.5 & 18.0 \\
Indianapolis, IN & 18.6 & 19.8 & 22.0 \\
Kansas City, MO & 31.6 & 28.3 & 0.5 \\
Los Angeles, CA & 20.1 & 20.6 & 19.9 \\
Memphis, TN & 20.0 & 23.0 & \\
\hline
\end{tabular}


Exhibit 11 (continued)

Returns for Recent Holding Periods

\begin{tabular}{|c|c|c|c|}
\hline \multirow[b]{2}{*}{ MSA } & \multicolumn{3}{|c|}{ Holding Periods } \\
\hline & 3 -Year $(\%)$ & 5 -Year $(\%)$ & 10 -Year $(\%)$ \\
\hline Miami, FL & 14.5 & 18.0 & 15.8 \\
\hline Milwaukee, WI & 15.2 & 14.4 & 14.7 \\
\hline Minneapolis, MN & 37.4 & 28.5 & 19.1 \\
\hline New Orleans, LA & 22.1 & 24.1 & 22.7 \\
\hline New York, NY & 31.0 & 22.6 & 9.2 \\
\hline Newark, NJ & 25.2 & 19.3 & 9.1 \\
\hline Norfolk, VA & 23.3 & 20.6 & 15.8 \\
\hline Oklahoma City, OK & 26.0 & 25.4 & 22.5 \\
\hline Philadelphia, PA & 21.2 & 17.2 & 9.1 \\
\hline Phoenix, AZ & 30.9 & 28.6 & 22.2 \\
\hline Pittsburgh, PA & 19.2 & 18.8 & 15.5 \\
\hline Portland, OG & 9.7 & 13.3 & 19.0 \\
\hline Providence, RI & 27.8 & 19.4 & 7.3 \\
\hline Riverside, CA & 29.2 & 27.0 & 5.5 \\
\hline Sacramento, CA & 36.5 & 26.0 & 7.0 \\
\hline Salt Lake City, UT & 4.2 & 10.6 & 22.3 \\
\hline San Diego, CA & 35.5 & 28.9 & 9.2 \\
\hline San Francisco, CA & 37.8 & 30.5 & 11.3 \\
\hline Seattle, WA & 20.2 & 22.2 & 12.9 \\
\hline St. Louis, MO & 25.9 & 22.9 & 17.6 \\
\hline Tampa, FL & 43.6 & 36.0 & 24.3 \\
\hline Washington, DC & 29.2 & 19.9 & 9.2 \\
\hline Mean & 24.8 & 22.4 & 15.2 \\
\hline Median & 25.6 & 22.8 & 15.8 \\
\hline Std. Dev. & 9.2 & 6.3 & 6.2 \\
\hline
\end{tabular}

Note: Holding periods ending 2001.4. Data assume a 30 -year, fixed rate loan, $80 \% \mathrm{~L} / \mathrm{V}$ ratio and a $28 \%$ tax rate.

Recent trends in homeowner returns for the 42 MSAs are presented in Exhibit 11, which shows returns for the most recent 3-, 5- and 10-year holding periods ending in 2001:4. Calculations in Exhibit 11 assume an $80 \%$ loan-to-value ratio and a $28 \%$ marginal tax bracket.

Acceleration in the recent level of returns is evident clearly in Exhibit 11. The average annual return for a 10 -year holding period in the 42 cities is $15.2 \%$, while the average for a 3 -year holding period is $24.8 \%$. The high level of recent returns accords with the recent surge in home buying and home construction across the country. 
A high level of variation in returns across cities also is plainly evident in Exhibit 11. The highest annual returns for the most recent 3-year holding period are recorded in Tampa and Denver at $43.6 \%$ and $38.7 \%$, respectively, while the lowest returns over the same period are in Buffalo and Salt Lake City at $3.7 \%$ and $4.2 \%$, respectively.

\section{Conclusion}

The purpose of this study is to examine the rate of return and risk of single-family, owneroccupied housing investment nationally and at the MSA level. Between 1978 and 2001, the average homeowner, using no leverage and with a $28 \%$ marginal tax rate, earned a compound annual return of $11.81 \%, 5.85 \%$ from implicit rental savings and $5.63 \%$ arising from the appreciation in home prices. With leverage, the returns over this period were substantially higher, but leverage also raised the level of risk.

The findings indicate that rates of return are higher for longer holding periods, while risk declines with greater holding periods. The tax subsidy provided by the interest deduction combined with the use of high leverage provides much higher rates of return for individuals in higher tax brackets. Even over a relatively short 3-year time horizon, high tax bracket homeowners reap much higher rates of returns than low tax rate individuals. During 1978-1996 (assuming 5-year holding periods, 80\% leverage and a 28\% marginal tax rate), homeownership stands between T-bonds and the S\&P 500 stock index in terms of its rate of return, but homeownership has higher risk than either bonds or stocks. Considered within the context of an investment portfolio, the advantage of homeownership arises because of its relatively low correlation with the stocks. However, the correlation with stocks rises substantially when housing investment is financed with high leverage.

The findings also indicate that the average rate of return and risk to homeownership varies as much as threefold among the sample of 42 MSAs. Recent returns have accelerated markedly in most of the MSAs examined, because of rising home values and falling mortgage rates.

\section{Endnotes}

1. see, Aizcorbe, Kennickell and Moore (2003).

2. Benjamin, Chinloy and Jud (2004) show that the decline in the stock market during 2000 and 2001 had a limited impact on aggregate demand because of an offsetting real estate wealth effect. They report that an additional dollar of real estate wealth increases consumption by 8 cents in the current year, as compared with only 2 cents for financial wealth.

3. Ibbotson and Siegel (1984) and Goetzmann and lbbotson (1990) find that long-run returns on residential real estate have been lower than the return on returns on stocks. These authors also find that investing in real estate has been a less risky investment, on average, compared with stocks as measured by the volatility of both investments. Other studies with similar conclusions include Hoag (1980), Burns and Epley (1982), Brueggeman, Chen and Thibodeau (1984), Zerbst and Cambon (1984) and Gau (1987).

4. see Benjamin, Sirmans and Zietz (2001) for a review of literature on risk and return on real estate investments.

5. Research indicating that there are price appreciation differentials based upon size and housing value include studies by Kiel and Carson (1990), Smith and Tesarek (1991) and Seward, Delaney 
and Smith (1992). Pollakowski, Stegman and Rohe (1991) find no significant relationship between housing value and appreciation during the 1974-83 period.

6. The distribution of taxation benefits of homeownership as it relates to class equality is not only a hotly debated research issue in the U.S.; Burbridge (2000) finds that the distribution of housing benefits in Sydney and Melbourne since deregulation has created a more unequal society because of the class bias it imposes.

7. An earlier study by Rosen and Rosen (1980) indicated that if personal income tax benefits from homeownership were removed, the proportion of homeowners in the long run would drop by about 4 percentage points; this implies that one quarter of the homeownership from 1945 to 1980 is attributable to tax factors. Cecchetti and Rupert (1996) report that the benefits of mortgage interest deduction are highest for family income between $\$ 100,000$ and $\$ 199,999$; the percentage of total tax savings reaches a maximum of $28 \%$ before declining to $21.6 \%$ for those families with $\$ 200,000$ or more of annual family income.

8. The "sweet spot" of their calculations appears to be about $11 \%$ to $12 \%$ for a wide range of holding periods. It's interesting to note that homeownership returns in England appear similar (though slightly higher) in the United Kingdom during this time period. Hutchison (1994) finds that housing returns vary from about $11.52 \%$ to $16.74 \%$ in seven key U.K. regions: London, Scotland, South-West, South-East, North-West, Yorkshire and Humberside during the 19841992 period. However, given the lack of proximity of these markets, the similarity is likely coincidental.

9. Borrowing from capital budgeting theory in the finance literature, housing space has an opportunity cost that should be included in an internal rate of return calculation. That is, housing space has an opportunity cost to the owner because it could be rented to a third party.

10. see, NIPA series, Table 8.12, Housing sector Output.

11. As is well known, adding leverage raises the after-tax return on an investment so long as the unlevered return after taxes is higher than the after-tax cost of debt. If the unlevered return is lower than the after-tax cost of debt, then adding leverage will lower the return.

12. Inflation is measured by the Consumer Price Index for All Urban Consumers (CPI-U). The return series for T-bills, T-bonds and the S\&P 500 are taken from Damodaran (2001) as reported on the author's website at: www.damodaran.com.

13. Although stock returns do not include the effects of personal leverage, systematic and unsystematic risk increase as corporate leverage rises. For example, Hamada (1972) shows that common stock betas can be "unlevered" or "relevered" based on the financial leverage of a company.

14. In calculating MSA returns, we use AHS data on annual property taxes, maintenance and insurance costs for the median homeowner as inputs in tabulating investment returns using Equation (1). AHS data on median rents and home values also allow us to adjust the imputed rent-to-value ratio for each MSA to reflect that MSAs rent-to-value ratio relative to the national average.

\section{References}

Aizcorbe, A. M., A. B. Kennickell and K. Moore, Recent Changes in U.S. Family Finances: Evidence from the 1998 and 2001, Survey of Consumer Finances, Federal Reserve Bulletin, 2003, 89, 1-32.

Alberts, W. W. and H. S. Kerr, The Rate of Return from Investing in Single-Family Housing, Land Economics, 1981, 57:2, 230-42. 
Barnes, M. H., Should You Invest in Real Estate?, The Bank Credit Analyst, 2002, May, 1932. Benjamin, J. D., P. Chinloy and G. D. Jud, Real Estate Versus Financial Wealth in Consumption, Journal of Real Estate Finance and Economics, 2004, 293, 341-54.

Benjamin, J. D., G. S. Sirmans and E. N. Zietz, Returns and Risk on Real Estate and Other Investments: Other Evidence, Journal of Real Estate Portfolio Management, 2001, 7:3, 183214. Berkovec, J. and D. Fullerton, A General Equilibrium Model of Housing, Taxes, and Portfolio Choice, The Journal of Political Economy, 1992, 100:2, 390-429.

Brueggeman, W. B., A. H. Chen and T. G. Thibodeau, Real Estate Investment Funds: Performance and Portfolio Considerations, Journal of the American Real Estate and Urban Economics Association, 1984, 12:3, 333-54.

Burbridge, A., Capital Gains, Homeownership and Economic Inequity, Housing Studies, 2000, $15: 2,259-80$.

Burns, W. L. and D. R. Epley, Performance of Portfolios of REITs and Stocks, Journal of Portfolio Management, 1982, 8:3, 37-42.

Case, K. and R. Shiller, Prices of Single Family Homes Since 1970: New Indexes for Four Cities, New England Economic Review, 1987, September-October, 45-56.

., Forecasting Prices and Excess Returns in the Housing Market, Journal of the American Real Estate and Urban Economics Association, 1990, 18:3, 253-73.

Cecchetti, S. G. and P. Rupert, Mortgage Interest Deductibility and Housing Prices, Economic Commentary, Federal Reserve Bank of Cleveland, February 1. 1996.

Coyne, T. J., W. M. Goulet and M. J. Picconi, Residential Real Estate Versus Financial Assets, Journal of Portfolio Management, 1980, 7:1, 20-4.

Crone, T. M. and R. P. Voith, Risk and Return within the Single-Family Housing Market, Real Estate Economics, 1999, 27:1, 63-78.

Damodaran, A., The Dark Side of Valuation, Upper Saddle River, NJ: Prentice Hall PTR, 2001. Devaney, M. and W. Rayburn, When a House is More than a Home: Performance of the Household Portfolio, Journal of Real Estate Research, 1988, 3:1, 75-85.

England, P., T. M. Gordon and J. M. Quigley, The Valuation of Real Capital: A Random Walk Down Kungsgatan, Journal of Housing Economics, 1999, 8:3, 205-16.

Ermer, C. M., S. M. Cassidy, and M. J. Sullivan, Modeling Returns to Owner-Occupied SingleFamily Residences, Journal of Economics and Finance, 1994, 18:2, 205-17.

Fuerbringer, J., Missing the 90's Bubble Looks Prescient in 2002, New York Times, July 24, 2002, C1.

Gau, G. W., Efficient Real Estate Markets: Paradox or Paradigm?, Journal of the American Real Estate and Urban Economics Association, 1987, 15:2, 1-12.

Goetzmann, W. N., The Single-Family Home in the Investment Portfolio, Journal of Real Estate Finance and Economics, 1993, 6:3, 201-22.

Goetzmann, W. N. and R. G. Ibbotson, Performance of Real Estate as an Asset Class, Journal of Applied Corporate Finance, 1990, 3:1, 65-76.

Greenspan, A., Speech to the 2001 Kansas City Federal Reserve Monetary Policy Conference, Jackson Hole, Wyoming, 2001.

Hamada, R. S., The Effect of the Firm's Capital Structure on the Systematic Risk of Common Stocks, Journal of Finance, 1972, 27:2, 435-52.

Harris, J., Investment Performance of Owner-Occupied Housing, American Real Estate Society Conference, Naples, FL, April 2002.

Hendershott, P. H. and S. C. Hu, Inflation and Extraordinary Returns on Owner-Occupied 
Housing: Some Implications for Capital Allocation and Growth, Journal of Macroeconomics, 1981, 3:2, 177-203.

Hoag. J. W.. Toward Indices of Real Estate Value and Return, Journal of Finance, 1980, 35:2, 569-80.

Hutchinson, N. E., Housing as an Investment?, Journal of Property Finance, 1994, 5:2, 47-61. lbbotson, R. G. and L. B. Siegel, Real Estate Returns: A Comparison with Other Investments, Journal of the American Real Estate and Urban Economics Association, 1984, 12:3, 219-42.

Kiel, K. A. and R. T. Carson, An Examination of Systematic Differences in the Appreciation of Individual Housing Units, Journal of Real Estate Research, 1990, 5:3, 301-17.

Liu, C. H., T. V. Grissom and D. J. Hartzell, The Impact of Market Imperfections of Real Estate Returns and Optimal Investor Portfolios, Journal of the American Real Estate and Urban Economics Association, 1990, 18:4,453-78.

Miller, N. G. and M. A. Sklarz, A Comment on Tax Rates and Implicit Rates of Return on Owner-Occupied Single-family Housing, Journal of Real Estate Research, 1989, 4:1, 81-4.

Peiser, R. B. and L. B. Smith, Homeownership Returns, Tenure Choice and Inflation, Journal of the American Real Estate and Urban Economics Association, 1985, 13:4, 343-60.

Pollakowski, H. O., M. A. Stegman and W. Rohe. Rates of Return on Housing of Low- and Moderate-Income Owners, Journal of the American Real Estate and Urban Economics Association, 1991, 19:3, 417-25.

Quigley, J. M. and C. L. Redfearn, Investment Returns and Price Discovery in the Market for Owner-Occupied Housing, 5lh Annual Conference of the Asian Real Estate Society, July 26-30, 2000.

Rosen, H. S. and K. T. Rosen, Federal Taxes and Homeownership: Evidence from Time Series, Journal of Political Economy, 1980, 88:1, 59-75.

Rosen, H. S., K. T. Rosen and D. Holtz-Eakin, Housing Tenure, Uncertainty, and Taxation, Review of Economics and Statistics, 1984, 66:3, 405-16.

Seward, J. A., C. J. Delaney and M. T. Smith, An Empirical Analysis of Housing Price Appreciation in a Market Stratified by Size and Value of the Housing Stock, Journal of Real Estate Research, 1992, 7:2, 195-205.

Sheffrin, S. M. and T. M. Turner, Taxation and House-Price Uncertainty: Some Empirical Estimates, International Tax and Public Finance, 2001, 8:4, 621-36.

Smith, B. A. and W. P. Tesarek, House Prices and Regional Real Estate Cycles: Market Adjustments in Houston, Journal of the American Real Estate and Urban Economics Association, 1991, 19:3, 396-416.

Smith, R. A., What to Do When the Conventional Wisdom is Wrong-Fearing a Bubble, Homeowners Cash Out; A Return to Renting, The Wall Street Journal, July 23, 2002, Dl. Tse, R. Y. C. and J. R. Webb, Property Tax and Housing Returns, Review of Urban and Regional Development Studies, 1999, 11:2, 114-26.

Webb, J. R. and J. H. Rubens, Tax Rates and Implicit Rates of Return on Owner-Occupied Single-Family Housing, Journal of Real Estate Research, 1987a, 2:2, 11-28.

., Tax Rates and Implicit Rates of Return on Owner-Occupied Single-Family Housing: A Reply, Journal of Real Estate Research, 1987b, 4:1, 85-6.

Zerbst, R. and B. Cambon, Real Estate Returns and Risks, Journal of Portfolio Management, 1984, 10:3, 5-20.

The authors thank Jim Webb, Stephen Roulac, Terry Clauretie and Marvin Wolverton for their helpful comments and suggestions. 
